\title{
Effect of Veneering Materials and Curing Methods on Resin Cement Knoop Hardness
}

\author{
Rubens Nisie TANGO \\ Mário Alexandre Coelho SINHORETI \\ Américo Bortolazzo CORRER \\ Lourenço CORRER-SOBRINHO \\ Rafael Leonardo Xediek CONSANI
}

Dental Materials Area, Department of Restorative Dentistry, School of Dentistry of Piracicaba, State University of Campinas, Piracicaba, SP, Brazil

\begin{abstract}
This study evaluated the Knoop hardness of Enforce resin cement activated by the either chemical/physical or physical mode, and light cured directly and through ceramic (HeraCeram) or composite resin (Artglass). Light curing were performed with either conventional halogen light (QTH; XL2500) for $40 \mathrm{~s}$ or xenon plasma arc (PAC; Apollo 95E) for $3 \mathrm{~s}$. Bovine incisors had their buccal surfaces flattened and hybridized. On these surfaces a mold was seated and filled with cement. A $1.5-\mathrm{mm}$-thick disc of the veneering material was seated over this set for light curing. After storage $\left(24 \mathrm{~h} / 37^{\circ} \mathrm{C}\right)$, specimens $(\mathrm{n}=10)$ were sectioned for hardness $(\mathrm{KHN})$ measurements in a microhardness tester ( $50 \mathrm{gf}$ load/ $15 \mathrm{~s}$ ). Data were submitted to ANOVA and Tukey's test $(\alpha=0.05)$. It was observed that the dual cure mode yielded higher hardness compared to the physical mode alone, except for direct light curing with the QTH unit and through Artglass. Higher hardness was observed with QTH compared to PAC, except for Artglass/dual groups, in which similar hardness means were obtained. Low KHN means were obtained with PAC for both Artglass and HeraCeram. It may be concluded that the hardness of resin cements may be influenced by the presence of an indirect restorative material and the type of light-curing unit.
\end{abstract}

Key Words: resin cement, hardness, resin composite, ceramic.

\section{INTRODUCTION}

The use of resin cements has grown in the last few years due to a larger application of indirect restorative materials, as ceramics and composite resins. As advantages, these cements present adhesion to substrates (by silane and adhesive agents), low solubility, easy handling and favorable esthetics when used with metal-free ceramic systems. The application of resin cements can still result in higher fatigue and compressive strength of ceramo-ceramic crowns compared to glass ionomer and zinc phosphate cements (1).

Despite the variety of currently available cements, there is no ideal material for all clinical situations. Therefore, the choice of the luting agent must rely on its physical, biological and handling properties allied to the characteristics of the prepared tooth and prosthesis (2). Factors, such as light-curing method and exposure time, use of an indirect restorative material and the luting agent have been shown to influence the final quality of restorations $(3,4)$. Inlays, onlays, laminated veneers and ceramo-ceramic crowns are commonly cemented with dual-cured resin cements because light transmission through indirect restorative materials is critical and the chemical reaction would theoretically guarantee a satisfactory polymerization. Linden et al. (5) verified that the light transmission spectrum through ceramics is influenced by its thickness and opacity. The application of longer light-exposure times results in higher polymerization depth, conversion degree and hardness $(3,6,7)$, which implicates in improved mechanical (8) and esthetic properties. Thus, the light

Correspondence: Prof. Dr. Mário Alexandre Coelho Sinhoreti, Faculdade de Odontologia de Piracicaba, UNICAMP, Área Materiais Dentários, Av. Limeira, 901, 13414-903 Piracicaba, SP, Brasil. Tel:+55-19-2106-5374. Fax: +55-19-2106-5218. e-mail: sinhoret@fop.unicamp.br 
exposure time recommended by the manufacturer should be regarded with caution (8).

Hardness testing is commonly used as a simple and reliable method to indicate the degree of conversion of resin-based cements (9). The degree of conversion in a polymerization reaction is dependent on the energy delivered during light curing, characterized as the product of light intensity and exposure time (10). Comparing materials of the same commercial brand, it was observed that, when light activated, dual-cure resin cements present higher hardness than light-cured materials (3). Witzel et al. (11) verified that, when not light activated cured and associated with one-bottle adhesive systems, dual-cured resin cements produced about $51 \%$ and $64 \%$ lower bond strengths than light-cured dual-cured cements.

Light curing is usually performed with quartz tungsten halogen (QTH) light-curing units (LCUs). Other technologies, such as xenon plasma arc (PAC) and light-emitting diodes (LED) are also available. Although these systems are still being developed, their application has grown considerably. Doubts about the effectiveness of light activation of resin cements with different methods using these LCUs still exist. Thus, the null hypothesis of this study is that similar resin cement hardness is obtained with different veneering materials, LCUs (QTH and PAC) and cement activation modes.

\section{MATERIAL AND METHODS}

Forty disc-shaped specimens $(1.5 \mathrm{~mm}$ height and $7 \mathrm{~mm}$ diameter) of each tested material - a feldspathic ceramic (HeraCeram; Heraeus Kulzer, Wehrhein, Germany; shade DD2) and an indirect composite resin (Artglass; Heraeus Kulzer; shade DD2) were fabricated.

The crowns of 120 freshly extracted bovine incisors were removed and embedded in polystyrene resin in plastic molds, keeping the buccal surface exposed. The buccal surfaces were ground flat under water cooling with \#200-, 400- and 600-grit SiC papers (Saint-Gobain, Recife, PE, Brazil) to obtain an exposed dentin area of at least $25 \mathrm{~mm}^{2}$. Prior to cementation, the dentin surfaces were etched with $37 \%$ phosphoric acid (Condicionador Dental Gel; Dentsply Ind. e Com. Ltda., Petrópolis, RJ Brazil) and hybridized with Prime\&Bond 2.1 adhesive system (Dentsply) according to manufacturer's instructions. For 60 specimens, each layer of material was light cured with a QTH LCU (XL
2500; 3M/ESPE Dental Products, St. Paul, MN, USA; $700 \mathrm{mWcm}^{-2}$ ) during $10 \mathrm{~s}$ and for the other 60 specimens each layer of material was light cured with a PAC LCU (Apollo 95E, DMD Equip. Ltd., Westlake Village, CA, USA; at $1600 \mathrm{mWcm}^{-2}$ ) during $3 \mathrm{~s}$.

The discs of veneering materials were etched with $10 \%$ hydrofluoric acid (Ceramic conditioner; Dentsply) and silanized (Silane; Dentsply) according to manufacturer's instructions. Enforce resin cement (Dentsply; shade A2) was used with 2 activation modes: dual cure and light cure alone. Twelve groups $(n=10)$ were formed by the combination of veneering materials, LCUs (QTH and PAC) and cement activation modes.

For cementation, a rubber mold with $5 \mathrm{~mm}$ diameter and $1 \mathrm{~mm}$ height was seated over the hybridized dentin and bulk filled with the resin cement. Over this set, a disc of the veneering material was digitally compressed for cement excesses flowing and removing (Fig. 1). During light activation, the LCU tip was in contact with the veneering material. Exposure time was $40 \mathrm{~s}$ for QTH and only $3 \mathrm{~s}$ for PAC.

After light curing, the specimens were stored dry in dark at $37^{\circ} \mathrm{C}$ during $24 \mathrm{~h}$. To perform resin cement Knoop hardness measurements, specimens were sectioned longitudinally under water with a diamond saw (Extec model 12205, Extec Corp., Enfield, CT, USA). The surface obtained by sectioning was polished sequentially under water cooling with \# 400-, 600- and 1200 -grit $\mathrm{SiC}$ papers.

Indentations and microhardness measurements (KHN) were performed in 3 sequences of 5 indentations each, in a micro-hardness tester machine HMV-2000 (Shimadzu, Tokyo, Japan). The direction of indentations was changed from one sequence to another. Indentations were performed at 100, 500 and $900 \mu \mathrm{m}$

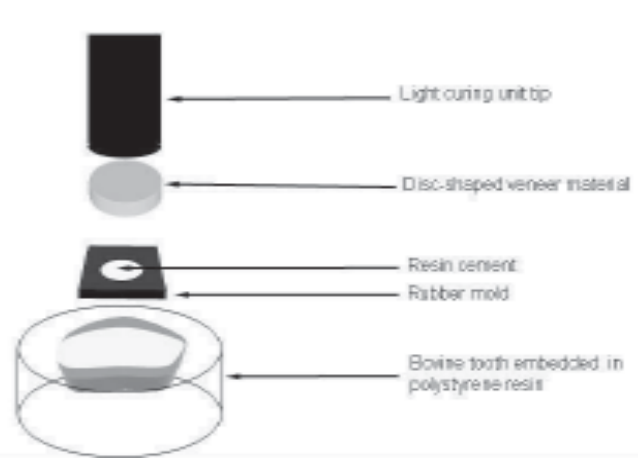

Figure 1. Schematic illustration of the light-curing procedure. 
from top surface (Fig. 2) with a $50 \mathrm{gf}$ load during $15 \mathrm{~s}$. For each specimen, a mean value was obtained from 15 measurements and data were submitted to three-way ANOVA and Tukey's test $(\alpha=0.05)$.

\section{RESULTS}

There was statistically significant difference $(p<0.05)$ among the factors (veneering materials, LCUs and cement activation modes) and also among their interactions $(p<0.05)$. Knoop hardness of the lightcured and dual-cured cements for each combination of LCU and veneering material are given in Table 1.

For QTH, only HeraCeram influenced the resin cement Knoop hardness, comparing the dual-cure and light-cure modes. For PAC, under all tested conditions, significant differences were found between the dualcure and light-cure modes (Table 1). Higher Knoop

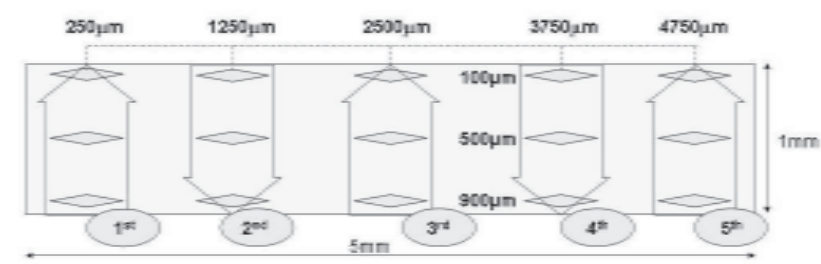

Figure 2. Schematic illustration of the sequence of Knoop hardness indentations.

Table 1. Comparison of hardness means (KHN) between lightcured and dual-cured cement for each combination of LCU and veneering material.

\begin{tabular}{lcc}
\hline & Dual-cured & Light-cured \\
\hline QTH & & \\
Direct & $45.05(4.73) \mathrm{a}$ & $44.35(1.29) \mathrm{a}$ \\
Artglass & $44.03(7.09) \mathrm{a}$ & $46.23(3.56) \mathrm{a}$ \\
HeraCeram & $41.47(5.94) \mathrm{a}$ & $34.84(2.77) \mathrm{b}$ \\
& & \\
PAC & & $25.71(5.14) \mathrm{b}$ \\
Direct & $38.15(2.91) \mathrm{a}$ & $0.00(0.00) \mathrm{b}$ \\
Artglass & $44.76(3.97) \mathrm{a}$ & $0.00(0.00) \mathrm{b}$ \\
HeraCeram & $39.19(4.55) \mathrm{a}$ & \\
\hline
\end{tabular}

Different letters in the rows indicate statistically significant differences between groups $(\alpha=0.05)$. Standard deviations are shown in parentheses. "Zero" values are illustrative. hardness was obtained when the resin cement was light cured with QTH compared to PAC, except for light activation through Artglass (Table 2).

Table 3 compares the veneering materials for each combination of LCU and cement activation mode. Light curing with QTH through HeraCeram resulted in lower hardness compared to the other veneering conditions, for both cement activation modes. For PAC, the highest hardness was obtained with light curing through Artglass. When the cement was light cured with interposed veneering materials, hardness could not be recorded.

Table 2. Comparison of hardness means (KHN) between groups light cured with QTH and PAC for each combination of cement activation mode and veneering material.

\begin{tabular}{lcc}
\hline & QTH & PAC \\
\hline Dual-cured & & \\
Direct & $45.05(4.73) \mathrm{a}$ & $38.15(2.91) \mathrm{b}$ \\
Artglass & $44.03(7.09) \mathrm{a}$ & $44.76(3.97) \mathrm{a}$ \\
HeraCeram & $41.47(5.94) \mathrm{a}$ & $39.19(4.55) \mathrm{b}$ \\
& & \\
Light-cured & & $25.71(5.14) \mathrm{b}$ \\
Direct & $44.35(1.29) \mathrm{a}$ & $0.00(0.00) \mathrm{b}$ \\
Artglass & $46.23(3.56) \mathrm{a}$ & $0.00(0.00) \mathrm{b}$ \\
HeraCeram & $34.84(2.77) \mathrm{a}$ & \\
\hline
\end{tabular}

Different letters in the rows indicate statistically significant differences between groups $(\alpha=0.05)$. Standard deviations are shown in parentheses. "Zero" values are illustrative.

Table 3. Comparison of hardness means (KHN) between veneering materials for each combination of cement activation mode and LCU.

\begin{tabular}{cccc}
\hline & Direct & Artglass & HeraCeram \\
\hline Dual-cured & & & \\
QTH & $45.05(4.73) \mathrm{a}$ & $44.03(7.09) \mathrm{a}$ & $41.47(5.94) \mathrm{b}$ \\
PAC & $38.15(2.91) \mathrm{b}$ & $44.76(3.97) \mathrm{a}$ & $39.19(4.55) \mathrm{b}$ \\
& & & \\
Light-cured & & & \\
QTH & $44.35(1.29) \mathrm{a}$ & $46.23(3.56) \mathrm{a}$ & $34.84(2.77) \mathrm{b}$ \\
PAC & $25.71(5.14) \mathrm{a}$ & $0.00(0.00) \mathrm{b}$ & $0.00(0.00) \mathrm{b}$ \\
\hline
\end{tabular}

Different letters in the rows indicate statistically significant differences between groups $(\alpha=0.05)$. Standard deviations are shown in parentheses. "Zero" values are illustrative. 


\section{DISCUSSION}

Composite resin light curing adresses two general goals: the first is related to clinical aspects and the second to materials properties (12), such as hardness, polymerization shrinkage stress and conversion degree. Ferracane (13) reported that the use of indirect methods like hardness testing is valid to predict, in some way, the degree of conversion of composites.

In this study, the light cure mode yielded lower hardness means than the dual cured mode of a rein cement (Table 1). These data are consistent with those of a previous study (3). Kramer et al. (14) suggested that the use of dual-cured cements could be favorable because the chemical initiators would complement a possible deficience of light activation. However, it has been observed that light activation of dual-cured cements had been neglected by clinicians because of their lack of knowledge of LCU characteristics. Peutzfeldt (15) have reported that when dual-cured cements are adequately light activated there is an increase of the conversion degree compared to dual-cured cements submitted exclusively to chemical activation. Thus, dual-cured cements should always be exposed to light activation.

In this study, with direct light curing or curing through 1.5-mm-thick increment of indirect material, it was possible to observe higher hardness means with dual cure mode compared to light cured alone, except for direct light curing and light curing with QTH through Artglass. In the groups of physically activated cement light cured through the veneering materials with PAC, it was not possible to record hardness means because the low polymerization led to large indentations, which exceeded the estrangement limit among the vertical bars of the micro-hardness view finder (Table 1). Perhaps, decreasing the load and the indentation time, hardness values could be obtained. However, in surfaces with higher hardness, these small indentations could lead to larger data variability.

Table 2 shows that light transmission also depends on the type of LCU, as reported elsewhere (16). According to Danesh et al. (17), the polymerization efficacy using PAC depends on the type and brand of the material to be cured. The manufacturer of the resin cement used in the present study (Enforce) recommends a 3-s exposure time with PAC. Hence, the energy density supplied to the material is much smaller than that supplied by QTH. Light curing with PAC for $3 \mathrm{~s}$, for being very fast, could not provide satisfactory polymerization of composites, which would present deficient properties (17).

In the present investigation, it was verified that the presence of a 1.5 -mm-thick layer of material interposed during irradiation decreased cement Knoop hardness, which confirm the attenuating property of veneering materials on resin cement polymerization previously reported by Hasegawa et al. (8). Brodbeldt et al. (18) verified that only about $0.13 \%$ of the light emitted by the LCU passed through a 1-mm-thick ceramic veneer.

In the dual cure and light cure modes, it was observed that veneering material influenced the results. In both activation modes, the cement when light cured through HeraCeram with QTH presented lower hardness in comparison to direct light curing and light curing through Artglass, which did not differ to each other. These data may be attributed to the different refraction indexes and opacity of the veneering materials because of their distinct nature (composite resin and ceramic). Additionally, the hardness means of the physically activated cement light cured with PAC, through Artglass and HeraCeram were significantly lower those obtained with direct light curing (Table 3).

In the dual cure mode, cement hardness under Artglass was not influenced by the type of LCU. Through HeraCeram, it can may be speculated that there was induction of the polymerization by light curing because lower hardness means were obtained with both QTH and PAC in comparison to Artglass. It may be assumed that, in these cases, the chemical polymerization complemented the setting reaction of the cement. According to Tables 2 and 3, the cement presented distinct behavior when light cured directly with different LCUs or through the same veneering material.

Proper exposure time and enough energy density should be applied to obtain better mechanical properties of composites (19). In general, the degree of polymerization of a composite is proportional to the amount of light it its exposed to; thus in higher depths, where there is lower light penetration, there is lesser conversion. According to Rasetto et al.(4), the same can be applied for resin cements. Therefore, for indirect light curing of composites using high intensity LCUs, manufacturers recommend that the exposure time should be increased to obtain similar hardness values of those obtained with direct light curing (20). The indirect restorative material in the same way, due to the light intensity attenuating characteristics, should to be taken into account to obtain 
the best properties of cements in order to prolong the clinical life of the restoration.

\section{RESUMO}

Este estudo avaliou a dureza Knoop do cimento resinoso Enforce ativado pelos modos químico/físico ou somente físico, fotoativados diretamente e através de cerâmica (HeraCeram) ou compósito (Artglass). A fotoativação foi realizada com luz halógena convencional (QTH; XL2500) por 40 s, e com arco de plasma de xenônio (PAC; Apollo 95E) por $3 \mathrm{~s}$. Incisivos bovinos tiveram suas faces vestibulares planificadas e hibridizadas. Sobre esta superfície foi assentada matriz, a qual foi preenchida com cimento. Um disco de material para faceta foi assentado sobre este conjunto para fotoativação. Após armazenagem $\left(24 \mathrm{~h} / 37^{\circ} \mathrm{C}\right)$, as amostras $(\mathrm{n}=10)$ foram seccionadas para leitura de dureza $(\mathrm{KHN})$, realizadas em aparelho micro-durômetro (50 gf / $15 \mathrm{~s}$ ). Os dados foram submetidos à análise de variância e ao teste de Tukey $(\alpha=0,05)$. Foi verificado que o cimento no modo dual apresentou maiores valores de dureza, comparado ao modo físico, exceto para fotoativação direta e através de Artglass com QTH. Valores mais altos de dureza foram observados com QTH comparado ao PAC, exceção aos grupos Artglass/dual, em que valores similares foram obtidos. Baixos valores de dureza Knoop foram obtidos com PAC com ambos o materiais Artglass e HeraCeram. Os valores de dureza dos cimentos resinosos podem ser influenciados pelo material restaurador indireto e também pelo tipo de aparelho fotoativador utilizado.

\section{ACKNOWLEDGEMENTS}

The authors acknowledge Dentsply and Heraeus Kulzer for supplying part of materials used in this study.

\section{REFERENCES}

1. Stappert CF, Guess PC, Chitmongkolsuk S, Gerds T, Strub JR. All-ceramic partial coverage restorations on natural molars. Masticatory fatigue loading and fracture resistance. Am J Dent 2007;20:21-26.

2. Fabianelli A, Goracci C, Bertelli E, Davidson CL, Ferrari M. A clinical trial of Empress II porcelain inlays luted to vital teeth with a dual-curing adhesive system and a self-curing resin cement. J Adhes Dent 2006;8:427-431.

3. Tango RN, Sinhoreti MA, Correr AB, Schneider LF, Kimpara ET, Correr-Sobrinho L. Knoop hardness of dental resin cements: Effect of veneering material and light curing methods. Polymer Test 2007;26:268-273.

4. Rasetto FH, Driscoll CF, von Fraunhofer JA. Effect of light source and time on the polymerization of resin cement through ceramic veneers. J Prosthodont 2001;10:133-139.

5. Linden JJ, Swift EJ Jr, Boyer DB, Davis BK. Photo-activation of resin cements through porcelain veneers. J Dent Res 1991;70:154-157.

6. Arrais CA, Giannini M, Rueggeberg FA, Pashley DH. Microtensile bond strength of dual-polymerizing cementing systems to dentin using different polymerizing modes. J Prosthet Dent 2007;97:99-106.

7. Filipov IA, Vladimirov SB Residual monomer in a composite resin after light-curing with different sources, light intensities and spectra of radiation. Braz Dent J 2006;17:34-38.

8. Correr AB, Sinhoreti MA, Correr Sobrinho L, Tango RN, Schneider LF, Consani S. Effect of the increase of energy density on Knoop hardness of dental composites light-cured by conventional QTH, LED and xenon plasma arc. Braz Dent J 2005; 16:218-224.

9. Obici AC, Sinhoreti MA, Frollini E, Correr-Sobrinho L, Goes MF, Henriques GE. Monomer conversion at different dental composite depths using six light-curing methods. Polymer Test 2006;25:282-288.

10. Obici AC, Sinhoreti MA, Frollini E, Correr-Sobrinho L, Consani S. Degree of conversion and knoop hardness of Z250 composite using different photo-activation methods. Polymer Test 2005;24:814-818.

11. Witzel MF, Braga RR, Singer JM, Azevedo CL. Bond strength between polymer resin-based cement and porcelain-dentin surfaces: influence of polymerization mode and early cyclic loading. Int J Prosthodont 2003;16:145-149.

12. Nagayassu MP, Shintome LK, Uemura ES, Araujo JE. Effect of surface treatment on the shear bond strength of a resinbased cement to porcelain. Braz Dent J 2006;17:290-295.

13. Ferracane JL. Correlation between hardness and degree of conversion during the setting reaction of unfilled dental restorative resins. Dent Mater 1985;1:11-14.

14. Kramer N, Lohbauer U, Frankenberger R. Adhesive luting of indirect restorations. Am J Dent 2000;13:60D-76D.

15. Peutzfeldt A. Dual-cure resin cements: in vitro wear and effect of quantity of remaining double bonds, filler volume, and light curing. Acta Odontol Scand 1995;53:29-34.

16. Rasetto FH, Driscoll CF, Prestipino V, Masri R, von Fraunhofer JA. Light transmission through all-ceramic dental materials: a pilot study. J Prosthet Dent 2004;91:441-446.

17. Obici AC, Sinhoreti MA, Correr Sobrinho L, Goes MF, Consani S. Evaluation of depth of cure and Knoop hardness in a dental composite photo-activated using different methods. Braz Dent J 2004;15:199-203.

18. Brodbelt RH, O'Brien WJ, Fan PL. Translucency of dental porcelains. J Dent Res 1980;59:70-75.

19. Moon HJ, Lee YK, Lim BS, Kim CW. Effects of various light curing methods on the leachability of uncured substances and hardness of a composite resin. J Oral Rehabil 2004;31:258264.

20. Dietschi D, Marret N, Krejci I. Comparative efficiency of plasma and halogen light sources on composite micro-hardness in different curing conditions. Dent Mater 2003;19:493500 .

Accepted May 23, 2007 